\title{
International Participation in Quality Assurance within the European Higher Education Area
}

\author{
Adriana Daniela Şerban \\ Centre for University Development and Quality Management, \\ Babeș-Bolyai University, 1. M. Kogălniceanu St. Cluj-Napoca, Romania \\ adriana.serban@ubbcluj.ro
}

\begin{abstract}
At the Berlin Ministerial Meeting in September 2003, ministers with responsibility for higher education tasked the Bologna Follow-up Group to undertake a stocktaking exercise on the progress made in three priority action lines - quality assurance, the two-cycle degree system and recognition of degrees and periods of study. The international participation and networking in quality assurance within the European Higher Education Area (EHEA) was established as one of the aspects that needs to be monitored. The group presented detailed reports at conferences held in Bergen (May 2005), London (May 2007), Leuven (April 2009), Bucharest (April 2012) and Yerevan (May 2015). The purpose of this paper is to present the comparative results of the five stocktaking exercises regarding the international participation within EHEA and to provide information about how the Romanian higher education system has faced this challenge.
\end{abstract}

Keywords. international participation, Bologna Scorecard; stocktaking exercise; Quality Assurance; EHEA. 
38 Journal of Research in Higher Education • Vol. I, No. 1, 2017

\section{Introduction}

At the Berlin meeting in September 2003, ministers with responsibility for higher education agreed that a stocktaking exercise should be conducted, to measure the progress made in implementing certain reforms within the European Higher Education Area (EHEA), regarding the three main directions: quality assurance, the two-cycle degree system and recognition of degrees and periods of study. They requested the Bologna Follow-up Group (BFUG) to develop the stocktaking process and to prepare detailed reports for the next ministerial meetings.

In March 2004, a group of experts were chosen to follow the aforementioned aspects. The working group consulted with partners including the European University Association (EUA), the National Unions of Students in Europe (ESIB) and the EURYDICE Network (a structure of the Education, Audiovisual and Culture Executive Agency/EACEA, which offers information, analyses and statistics regarding European higher education) and presented detailed reports during conferences of the ministers responsible with higher education at Bergen (May 2005), London (May 2007), Leuven (April 2009), Bucharest (April 2012) and Yerevan (May 2015). Along with the material prepared by EURYDICE, the National Reports of the participant countries represented the main source of information for the stocktaking exercise.

For developing the Bologna Scorecard, the working group reviewed each of the three actions lines, and elaborated key criteria. Each criterion was further expanded on the basis of five benchmarks (levels of achievements), which would serve to measure the extent of progress:

1. Little progress has been made yet (level 1)

2. Some progress has been made (level 2)

3. Good performance (level 3)

4. Very good performance (level 4)

5. Excellent performance (level 5)

In the context of the Bologna process, between 2005 and 2015, European higher education was marked by several important events European Standards and Guidelines (ESG) were adopted in 2005 and reviewed in 2015, the compiling of the European Quality Assurance 
Register (EQAR) has started in 2008, the same year the European Qualification Framework (EQF) based on learning outcomes was adopted, followed by the development and the implementation of the National Qualification Framework in the EHEA member countries.

\section{Methodology}

In order to identify the context and the requirements for international cooperation in quality assurance in European higher education, a document analysis was developed. The investigation approach is Cartesian (Ghiglione \& Matalon, 1987 in Ilut 1997), the investigation being carried out in a quantitative manner, associated with the identification of both the context and the message content.

Aiming to explore how Romania faced the challenge of international participation in quality assurance, an individual instrumental (Stake, in Denzin and Lincoln 1994), i.e.a descriptive case study (Yin 2005), was conducted. This country is a full member of EHEA since 1999, also being the first ex-communist nation state that, due to its progress in quality assurance, hosted a conference of the ministers responsible with higher education (Bucharest 2012).

In the pre-analytical stage, the floating reading of the five reports on the Bologna Scorecards results was performed for the construction of the document's body (Moscovici \& Buschini 2007). This revealed the necessity of a longitudinal comparative approach and suggested the key-words for the analysis. The documents sample was set to the five reports submitted by the working group for the conferences of the ministers responsible with higher education (Bergen 2005, London 2007, Leuven 2009, Bucharest 2012 and Yerevan 2015) and the five Romanian National Reports. In order to complete the outlined sketch, but without insisting on a rigorous analysis, we also refer to other six important documents regarding the quality assurance process of the Romanian higher education system, namely:

1. Emergency Ordinance no. $75 / 2005$ concerning the quality assurance of the educational services

2. Law no. 87/2006 for approving EO no.75/2005

3. "Methodology for External Evaluation, Standards, Reference Standards and List of Performance Indicators" of the Romanian 
40 • Journal of Research in Higher Education • Vol. I, No. 1, 2017

Agency for Quality Assurance in Higher Education (ARACIS) (2006)

4. Guide for Quality Evaluation of University Study Programs and Higher Education Institutions, an 2006 ARACIS document which supports current changes when necessary

5. Law of National Education no. 1/2011

6. Emergency Ordinance no. 75/2011 (completing the EO no. $75 / 2005)$

The documents' selection was conceived following the criterion of their significance for the proposed resolution (Ragin 2006) as well as their degree of similitude (Durkheim 1895/2002). The construct equivalent (Mills et al 2006) is assured by the fact that the documents are conceived by the same authorities and have the same purpose.

The key-words we have used (and topics linked on) were international, external, outside the country, other country, border, open, participation/collaboration, and peers/experts/team. The documents in their entirety were considered the analysis units, and the text message was determined as communication element.

Considering the triangulation principle and aiming for a deeper analysis of the case study, in addition to the comparative register, the website of the Romanian Agency for Quality Assurance in Higher Education (ARACIS) was consulted, in order to identify the level of the international experts' participation in the evaluation process of the Romanian higher education institutions.

\section{The international participation scorecards}

On Quality Assurance (QA), the Berlin Communiqué (2003) stated that by 2005 national quality assurance systems should include:

- A definition of the responsibilities of the bodies and institutions involved;

- An evaluation of programmes or institutions, including internal assessment, external review, participation of students and the publication of results;

- A system of accreditation, certification or comparable procedures;

- International participation, co-operation and networking. 
Based on this statement, the working group established the following criteria:

1. Stage of development of quality assurance system;

2. Key elements of evaluation systems;

3. Level of participation of students;

4. Level of international participation, co-operation and networking.

The 2005 report's conclusion regarding the QA process was that the great majority of countries have made excellent or very good progress; however, a low level of students' and international participation was also underlined. The indicators for the international participation were targeted on the national bodies for quality assurance, their governance and membership (Table 1). The results showed that only 12 of the 40 participant countries (there are two separate scores for three of the countries: Belgium, Serbia and Montenegro, and for the United Kingdom) had international participation in the governance of national bodies for QA, namely Austria, Belgium (both Flemish and French Communities), Cyprus, Czech Republic, Denmark, Germany, Ireland, Netherlands, Norway, Switzerland and United Kingdom (except Scotland). According to the national reports, the main barrier consisted in legal or statutory issues as well as language obstacles. More often the participants (16 countries) declared their involvement in teams for external review.

In 2007, five more countries were included - Armenia, Azerbaijan, Georgia, Moldova and Ukraine. The criterion for international participation in quality assurance became more challenging. For the excellent performance benchmark, another request was added, consisting ofthe external evaluation of quality assurance agencies. In the same time, including foreign experts in the governance of national bodies for quality assurance or as members of external review was still an issue. This is why only 11 of the 45 countries met the demands for level 5 (excellent performances) and 16, for level 3 (good performances), while there were 3 countries where some progress has been made (level 2) and 4 countries having no international involvement or no clarity regarding the structures and arrangements on this purpose. One of the report's conclusions is that extending the level of international participation is one of the main concerns and it needs significant effort to be carried out. 
Table 1. The indicators for the international participation criterion

\begin{tabular}{|c|c|c|c|}
\hline \multicolumn{3}{|c|}{ Level of international participation, co-operation and networking } & \multirow{2}{*}{$\begin{array}{l}\text { No. of } \\
\text { countries } \\
12\end{array}$} \\
\hline \multirow{5}{*}{2005} & 5 & $\begin{array}{l}\text { International participation at three levels: } \\
\text { - in the governance of national bodies for QA } \\
\text { - in teams for external review } \\
\text { - membership of ENQA or other international networks }\end{array}$ & \\
\hline & 4 & International participation at two of the three levels & 16 \\
\hline & 3 & International participation at one of the three levels & 6 \\
\hline & 2 & $\begin{array}{l}\text { Involvement in other forms of transnational co-operation in } \\
\text { executing QA }\end{array}$ & 9 \\
\hline & 1 & $\begin{array}{l}\text { No international participation yet OR no clarity about } \\
\text { structures and arrangements for international participation. }\end{array}$ & 0 \\
\hline \multirow{5}{*}{2007} & 5 & $\begin{array}{l}\text { International participation takes place at four levels: } \\
\text { - in the governance of national bodies for quality assurance } \\
\text { - in the external evaluation of national QA agencies } \\
\text { - as members or observers within teams for external review } \\
\text { of Higher education institutions and/or programmes } \\
\text { - membership of ENQA or other international networks. }\end{array}$ & 11 \\
\hline & 4 & International participation at three of the four above levels & 14 \\
\hline & 3 & International participation at two of the four above levels & 16 \\
\hline & 2 & International participation at one of the four above levels & 3 \\
\hline & 1 & $\begin{array}{l}\text { No international involvement OR no clarity about structures } \\
\text { and arrangements for international participation }\end{array}$ & 4 \\
\hline \multirow[t]{3}{*}{2009} & 5 & $\begin{array}{l}\text { In all cases, there is international participation at four levels: } \\
\text { - in the governance of national bodies for quality assurance } \\
\text { - in the external evaluation of national QA agencies } \\
\text { - as members or observers within teams for external review } \\
\text { of Higher education institutions and/or programmes } \\
\text { - membership of ENQA or other international } \\
\text { networks }\end{array}$ & 16 \\
\hline & 4 & $\begin{array}{l}\text { International participation takes place at above levels: } 1 \text { ); 2) } \\
\text { AND either } 3 \text { ) or } 4 \text { ). }\end{array}$ & 12 \\
\hline & 3 & $\begin{array}{l}\text { International participation takes place at levels 1) and 2) } \\
\text { listed above. }\end{array}$ & 4 \\
\hline
\end{tabular}




\begin{tabular}{|c|c|c|c|}
\hline \multicolumn{3}{|c|}{ Level of international participation, co-operation and networking } & \multirow{2}{*}{ 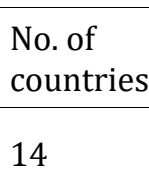 } \\
\hline & 2 & $\begin{array}{l}\text { International participation takes place either at level 1) or 2) } \\
\text { listed above. }\end{array}$ & \\
\hline & 1 & $\begin{array}{l}\text { There is no international involvement or structures and } \\
\text { arrangements for international participation are not yet clear. }\end{array}$ & 2 \\
\hline \multirow[t]{5}{*}{2012} & 5 & $\begin{array}{l}\text { In all cases the following four aspects are met: } \\
\text { - international peers/expert participate in governance of } \\
\text { national QA bodies } \\
\text { - international peers/experts participate as } \\
\text { members/observers in evaluation teams } \\
\text { - international peers/experts participate in follow-up } \\
\text { procedures } \\
\text { - agencies are full members of ENQA and/or listed on EQAR }\end{array}$ & 8 \\
\hline & 4 & Three of the four aspects are met & 11 \\
\hline & 3 & Two of the four aspects are met & 10 \\
\hline & 2 & One of the four aspects are met & 11 \\
\hline & 1 & No international participation & 7 \\
\hline \multirow[t]{5}{*}{2015} & 5 & $\begin{array}{l}\text { In all cases the following four aspects are met: } \\
\text { - international peers/expert participate in governance of } \\
\text { national QA bodies } \\
\text { - international peers/experts participate as } \\
\text { members/observers in evaluation teams } \\
\text { - international peers/experts participate in follow-up } \\
\text { procedures } \\
\text { - agencies are full members of ENQA and/or listed on EQAR }\end{array}$ & 10 \\
\hline & 4 & Three of the four aspects are met & 16 \\
\hline & 3 & Two of the four aspects are met & 9 \\
\hline & 2 & One of the four aspects are met & 8 \\
\hline & 1 & No international participation & 5 \\
\hline
\end{tabular}

Notes. There are two separate scores for three of the countries: Belgium, Serbia and Montenegro, and the United Kingdom.

The highlighted cells in the right column indicate the position of Romania.

In 2009, the requirements to be fulfilled for achieving the third level of performance were both the international participation in review teams and the membership of an international QA network, as well . As a result, 14 of the 45 countries involved reached only level 2 (some progress has been made). The report underlined that there has been 
some progress towards achieving a greater level of international involvement but the fact that quality assurance agencies from only 22 countries were full members of ENQA was unsatisfactory.

The 2012 report shows that the international participation in QA was highly uneven across the EHEA. As a first indicator, the criterion required the QA agencies to be full members of ENQA and/or listed on EQAR, along with other three indicators regarding the international peers/expert involvement in governance of national QA bodies, in evaluation teams or in follow-up procedures. Only eight countries reached level 5 of performance: Belgium (both Flemish and French Communities), Denmark, France, Ireland, Netherlands, Norway and Switzerland. Other seven countries were identified with no international participation: Azerbaijan, Georgia, Malta, Serbia and Montenegro, Turkey and Ukraine.

Investigating the character and orientation of national quality assurance system, in 2012 the ability for higher education institutions to be evaluated by an agency from outside their country was examined. The authorities of 14 countries declared that all higher education institutions can be evaluated by an agency outside the national system. A further eight countries stated that in some cases higher education institutions are able to recourse to this procedure. However, because of the various legal provisions, the report revealed that there was a very diverse picture regarding this issue within EHEA.

For the 2015 report, the indicators concerning the international participation in QA were kept in their previous format. Data shows that the process of internalisation was growing since 2012, listing on EQAR and membership of ENQA displaying a significant progress, especially in Central and Eastern Europe countries. Also, involving international experts in national quality assurance processes became a mandatory norm in several states. The picture reveals 26 of 45 participant countries reaching very good or excellent performances.

The Bucharest Communiqué stated that opening up the possibility for higher education institutions to be evaluated by foreign agencies is one of the major commitments in the context of the Bologna Process. The results of the investigation conducted in 2012 led to the decision of the working-group to introduce this issue as a criterion for the external quality assurance in 2015. The developed scorecard demands show the 
level of openness to cross border quality assurance activity of EQAR registered agencies, with the following categories:

Level 5

8 countries

Level 4

4 countries

Level 3

8 countries

Level 2

5 countries

Level 1

23 countries
All institutions and programmes can choose to be evaluated by a foreign QA agency to fulfil their obligations for external QA, while complying with national requirements. EQAR registration serves as a criterion for agencies to be allowed to carry out cross-border evaluation/accreditation/audit.

In some cases, institutions and/or programmes can choose to be evaluated by a foreign QA agency to fulfil their obligations for external QA, while complying with national requirements. EQAR registration serves as a criterion for agencies to be allowed to carry out cross-border evaluation/accreditation/audit.

In some or all cases, institutions and/or programmes can choose to be evaluated by a foreign QA agency to fulfil their obligations for external QA, but EQAR registration is not a criterion used to determine which agencies are allowed to carry out such cross-border evaluation/accreditation/audit.

Discussions are on-going or plans have been made to establish a legal framework allowing EQAR-registered agencies to operate in the country.

Institutions and programmes cannot be evaluated by $\mathrm{QA}$ agencies from outside the country to fulfil their obligations for external QA, and no plans are being discussed.

The results showed no significant progress since 2012. The findings were that level 5 was reached by 8 countries: Armenia, Bulgaria, Denmark, Germany, Azerbaijan, Liechtenstein, Poland and Romania. At the other end of the scale, there were 23 countries where institutions and programmes cannot be evaluated by QA agencies from outside their country.

The 2015 report concluded that higher education institutions are seeking to take advantage of collaborating with agencies from other countries, but the targeted national reforms on this objective are slowmoving. 
46 • Journal of Research in Higher Education • Vol. I, No. 1, 2017

\section{Case study. The Romanian international involvement in quality assurance}

Romania is a full member of the EHEA since 1999 and the first excommunist country that, due to its progress in quality assurance, hosted a conference of the ministers responsible with higher education (Bucharest, 2012). Between 2004 and 2006 the required legislative framework for the implementation of the Bologna Process was developed. In June 2004, the Romanian Team of Bologna Promoters (TBP) was formed with suport of the European Commission and included representatives of leading and staff of higher education institutions, representatives of students and of the National Council for Academic Evaluation and Accreditation (CNEAA) (a structure under parliamentarian control, having subordinated commissions of evaluation in fields and/or specializations, all functioning based on the regulations approved through governmental decision).

The general score for Romania in 2005 on quality assurance for the Level of international participation, co-operation and networking, was of good performance (level 3), along with other five countries: France, Italy, Malta, Russia and Slovenia.

The 2005 national report affirms the academic authonomy, also stated in the Romanian Constitution, and specified through the Education Law no 84/1995. The document shows that in Romania, the Ministry of Education is responsible for the national evaluation system in the entire education and, according to Law no. 88/1993, since 1993 the National Council for Academic Assessment and Accreditation (CNEEA) has been responsible for quality assurance and accreditation procedures in the Romanian higher education area. The report also mentioned that CNEAA has no tasks concerning the international participation to the quality assurance process; instead, it is stated the fact that a new structure is to be developed - the Romanian Agency for the Quality Assurance in High Education (ARACIS) - which will carry these responsibilities.

Between 2005 and 2007, Romania adopted a few important documents such as: the Order of the Minister of Education no. 3928 from April 2005 concerning the quality of the educational services in higher education, the Emergency Ordinance no. 75 from July 2005 concerning the quality assurance of the educational services, and Law 
no. 87/2006 for approving this ordinance. The 2007 National Report mentions as main achievements that the new adopted documents incude provisions regarding the establishment of the Romanian Agency for Quality Assurance in Higher Education (ARACIS) as an independent public institution of national interest, with legal personality and its own income and expenses, having competencies in accreditation, academic evaluation and external quality assurance. For the higher education institutions, Law no. 87/2006 provides the opportunity of external evaluation by other national or international agencies, based on a contractsigned either by the Ministry of Education and Research or by the academic institution to be evaluated.

In 2006, ARACIS elaborated the external evaluation methodology that included the opportunity to include international experts, if possible, but not mandatorily, for the evaluation team and for the higher education institutions as well.

Like in 2005, the Bologna Scorecard for Romania in 2007 showed a good performance (level 3) for the International participation criterion, along with other fifteen countries: Albania, Belgium (the French Community), Bulgaria, Estonia, Finland, Iceland, Lichtenstein, Lithuania, Malta, Moldova, Russia, Serbia, Slovenia, Macedonia and Turkey.

It must be underlined that in 2007, Romania became a member of the European Union, this status bringing several obligations that Romania undertook, including important transformations of the higher education system.

In the process of the national implementation of the Standards and Guidelines for Quality Assurance in the EHEA, the European University Association (EUA) was invited to conduct an audit of ARACIS that took place during the academic year 2007/2008. Also in August-September 2008, the European Student Union (ESU) was invited to conduct an external evaluation of ARACIS, the results being comparable to those reported by the EUA. Following these steps, ARACIS initiated the process to become a full member of ENQA and to be registered in EQAR, events which took place in 2009.

The 2009 national report mentioned these achievements and also declared that international participation and cooperation in QA is carried out through involvement in various teams of evaluators as a member or observer. As a result, Romania reached level 4 (very good performances) on the scorecards for this criterion, as well as other 
eleven countries: Finland, Germany, Hungary, Latvia, Lithuania, Luxemburg, Poland, Portugal, Spain, Macedonia and Turkey.

On international participation in 2012, Romania reached only level 2 (some progress has been made), alongside 10 other participants: Albania, Bosnia and Hertzegovina, Estonia, Hungary, Italy, Lithuania, Moldova, Northern Ireland, Slovakia, United Kingdom (except Scotland). The Romanian national report underlined that, according to the National Education Law adopted in 2011 and the Emergency Ordinance no. 75/2011 (completing the OE no. 75/2005), all higher education institutions can benefit from the opportunity of being evaluated by an outside country agency, which has to be an EQAR member.

This report also shows that international evaluators are involved in the external quality assurance process but not in governance structures, decision making processes or follow-up procedures, neither as full members, nor as observers in external review teams. No other information was provided on this subject. On the other hand, besides the ARACIS evaluation methodology (2006) which, as it was already mentioned, recommends the presence of an international evaluation expert, the changes made in 2010 to the ARACIS document "Guide for Quality Evaluation of University Study Programs and Higher Education Institutions" underlined that in the evaluation team an independent international expert must be included. However, starting with 2008, the international expert's report for each institution can be accessed on the ARACIS website, which hosts all the institutional evaluation reports of the team members. While these papers do not have a standardized form, their content is similar, referring to all major academic areas like structure, programs, students, staff, internationalization, specific outline, students' facilities, research activities.

In 2015, on the international participation, Romania obtained very good performance (level 4) as well as other fifteen participants: Albania, Serbia and Montenegro, Poland, Czech Republic, Austria, Slovenia, Lithuania, Portugal, United Kingdom (including Scotland), Northern Ireland, Russia, Iceland, Belgium (the Flemish Community). The National Report states that there are formal requirements for international experts to be involved as full members in external review teams and in follow-up procedures.

Regarding the level of openness to cross border quality assurance activity of EQAR registered agencies, the scorecards result for Romania 
showed, as it was mentioned before, excellent performances (level 5), similar with other seven countries: Armenia, Bulgaria, Denmark, Germany, Kazakhstan, Liechtenstein and Poland.

\section{Conclusions}

The longitudinal comparative approach of the Bologna Scorecards results presented the European framework regarding the international participation on quality assurance within EHEA and leads to the conclusion that this issue is still a problem. According to the 2015 working group report, this area of QA registered the lowest progress since 2005, and it is highly uneven across the EHEA.

The study revealed a very diverse picture of this phenomenon, on both longitudinal and transversal directions. The source of the differences along the longitudinal axis is the fact that every year the criteria became more challenging. According to the national reports of the participant countries, the roots of variety on the transversal axis consist in legal or statutory issues as well as language obstacles.

In 2005, 12 of the 40 participant countries reached the requirement for level 5 - excellent progresses benchmark (Figure 1), which was the international participation at three levels: in the governance of QA national bodies, in the external review teams and membership of ENQA or other international networks. In 2007, the international participation in external evaluation of the national QA agencies was introduced as mandatory, thus only 11 of the 45 countries achieved the highest level of performance. In 2009, the indicators used in 2007 were maintained, but their grouping manner for achieving certain level of performance was more challenging; consequently, only 16 of the 45 participant countries reached level 5 . The international peers/experts participation in follow-up procedures was a new request in 2012 and 2015; 8 countries reached the highest level of performance in 2012 and 10 in 2015. 


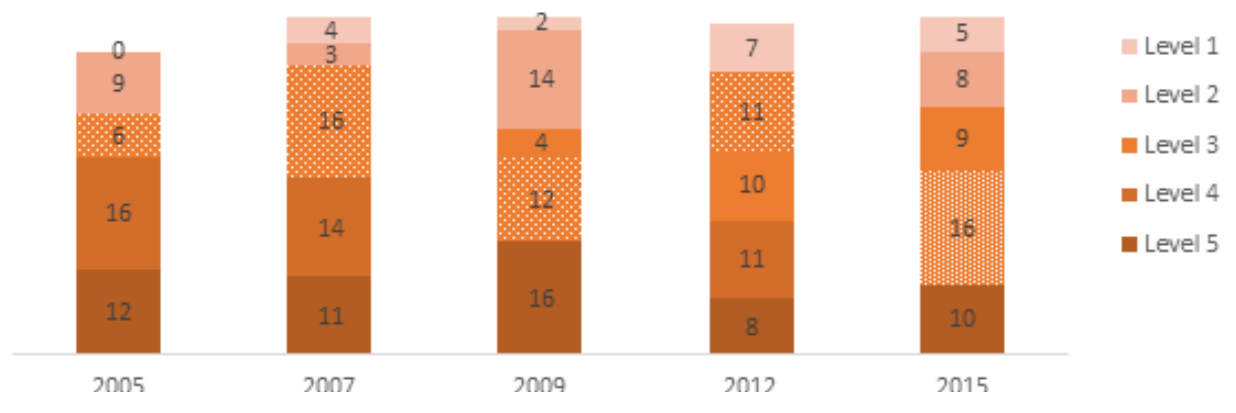

Figure 1. Number of countries situated on each level of performance (the areas with pattern fill represent the Romanian results)

Romania also faced higher targets every year, being an EHEA member since 1999. Due to its progress regarding quality assurance in higher education, it was the first ex-communist country hosting a conference of the ministers responsible with the higher education (Bucharest 2012). Between 2004 and 2006, the requirements for the implementation of Bologna system were undertaken, and between 2005 and 2007 several important documents concerning quality assurance in education were adopted. The working group that developed the Bologna scorecards exercise evaluated Romania's achievements on international participation in QA as good performances (level 3) in 2005 and 2007, as very good performances (level 2) in 2009 and 2015, and stated that some progress has been made (level 4) in 2012.

The Romanian case study, especially the recorded decrease in 2012 has brought to light another possible reason for the results' inconstancy, namely reasons related to the accuracy of the reported information and/or to the various perspective on the international participation concept. 


\section{References}

Bologna Process Stocktaking Report 2007. Report from a working group appointed by the Bologna Follow-up Group to the Ministerial Conference in London, May 2007. European Commission,

http://media.ehea.info/file/WGStocktaking/16/7/Stocktaking_r eport2007_581167.pdf.

Bologna Process Stocktaking Report 2009. Report from working groups appointed by the Bologna Follow-up Group to the Ministerial Conference in Leuven/Louvain-la-Neuve, 28-29 April 2009. European Commission, http://media.ehea.info/file/2009_Leuven_Louvain-laNeuve/94/7/Stocktaking_report2009_FINAL_594947.pdf.

Bologna Process Stocktaking Report from a working group appointed by the Bologna Follow-up Group to the Conference of European Ministers Responsible for Higher Education, Bergen, 19-20 May 2005. European Commission, http://media.ehea.info/file/WG _Stocktaking/96/1/BPStocktaking9May2005_578961.pdf.

Durkheim, E. (2002) Regulile metodei sociologice / The Rules of Sociological Method, Polirom, Iaşi.

Emergency Ordinance no. 75/2005, www.cnfis.ro/documente/pdf/OU752005.pdf.

Emergency Ordinance no. 75/2011,

http://www.dreptonline.ro/legislatie/oug_75_2011_modificare_oug_75

_2005_asigurarea_calitatii_educatiei.php.

Ghidul Activităților de Evaluare a Calității Programelor de Studii Universitare și a Instituțiilor de Învățământ Superior / Guide for Quality Evaluation of University Study Programs and Higher Education Institutions,

http://www.aracis.ro/fileadmin/ARACIS/Proceduri/partea_I__acredidare_programe licenta_si_master_Aprilie_2010.pdf.

Iluţ, P. (1997) Abordarea calitativă a socioumanului / Qualitative Approach of Sociouman., Polirom, Iaşi.

Law no. 87/2006,

http://www.uaic.ro/uaic/bin/download/Academic/ServiciulCali tate/legea87.pdf. 
52 • Journal of Research in Higher Education • Vol. I, No. 1, 2017

Law of National Education no. 1/2011, http://www.dreptonline.ro/legislatie/legea_educatiei_nationale_ lege_1_2011.php.

Methodology for External Evaluation, Standards, Standards or Reference, and List of Performance Indicators of the Romanian Agency for Quality Assurance in Higher Education (ARACIS) (2006),

http://www.aracis.ro/fileadmin/ARACIS/Proceduri/Methodolog y_for_External_Evaluation.pdf.

Mills, M., van de Bunt, G., de Brujin, J. (2006) "Comparative Research:

Persistent Problems and Promising Solutions", International Sociology. 21 (5): $619-632$.

Moscovici, S., Buschini, F. (2007) Metodologia ştiinţelor socioumane / Methodology in Sociouman Sciences, Polirom, Iaşi.

National Report regarding the Bologna Process implementation, 2009$2012 . \quad$ Romania. EHEA, http://media.ehea.info/file/Romania/94/2/National_Report_Ro mania_2012_571942.pdf.

National Report regarding the Bologna Process implementation, 20122015. Romania,

http://media.ehea.info/file/Romania/94/4/National_Report_Ro mania_2015_571944.pdf.

Ragin, C. (2006) "How to Lure Analytic Social Science Out of the Doldrums: Some Lessons from Comparative Research", International Sociology. 21 (5): 633 - 646.

Romania National Report. Bergen 2005. EHEA, http://media.ehea.info/file/Romania/93/6/National_Report_Ro mania 2005 571936.pdf.

Romania National Report. Leuven 2009. EHEA, http://media.ehea.info/file/Romania/94/0/National_Report_Ro mania 2009_571940.pdf.

Romania National Report. London 2007. EHEA, http://media.ehea.info/file/Romania/93/8/National_Report_Ro mania_2007_571938.pdf.

Stake, R. E. (1994) Case Studies. In Denzin, N. K., Lincoln, Y. S. (eds.) Handbook of Qualitative Research. Sage Publications, New York, pp. $236-247$. 
The European Higher Education Area in 2012. Bologna Process Implementation Report. European Commission, http://media.ehea.info/file/2012_Bucharest/79/5/Bologna_Pro cess_Implementation_Report_607795.pdf.

The European Higher Education Area in 2015. Bologna Process Implementation Report. European Commission, http://eacea.ec.europa.eu/education/eurydice/documents/the matic reports/182EN.pdf.

Yin, R. K. (2005) Studiul de caz. Designul, analiza şi colectarea datelor / Case Study Research. Design, analysis and data collection. Polirom, Iaşi.

\section{Online sources}

European Association for Quality Assurance in Higher Education (ENQA), www.enqa.eu.

European Quality Assurance Register (EQAR), www.eqar.eu.

European Higher Education Area (EHEA), www.ehea.info.

Romanian Agency for Quality Assurance in Higher Education (ARACIS), www.aracis.ro. 
